\title{
GILBERT MURRAY
}

Gilbert Murray, President of the Hellenic Society 1945-1947, was born at Sydney on January 2, I866, and died at Yatscombe on May 20, 1957. His ashes are in Westminster Abbey.

Murray's grandfather fought at Waterloo; his father was President of the Legislative Assembly of New South Wales. They were Irishmen. Of the children Murray writes :I "We tended to be agin the Government ... "Pity is a rebel passion," and we were ... passionately on the side of those likely to be oppressed.' At Southey's school, in the bush near Nattai, Murray's first fight was with a bully. 'I began Greek there, and my first word was pov̂oa (of course they pronounced it as if it was a word of praise for a cat).' He left at the age of eleven for England and Merchant Taylors'. At Oxford (St. John's) his tutors included Arthur Sidgwick and Samuel Alexander, his undergraduate friends Charles Gore and H. A. L. Fisher. He won all the classic events, ending with a Fellowship of New College (1888) and the Derby (1889); he made 40 in the Freshmen's match (1885; he had already, with his elder brother Hubert, entertained the victorious Australians to dinner after the Oval Test Match in I882); he also moved at the Union 'a motion of my own choice ... a warning of the great danger that threatened all Europe from the militarist powers of Germany and Russia and an appeal to the free nations to unite. . . . After a year at New College he succeeded Jebb in the Chair of Greek at Glasgow.

'Middle-aged responsibility came before its time': Glasgow, Murray said, had robbed him of his youth, yet he never loved another job so much. . It taught him to keep order and perfect a skill of lecturing for students who might occasionally be rough, but who insisted on being well taught. Not all of them were rough; among his pupils were John Buchan, H. N. Brailsford, and Janet Spens, who, if she was not the first to rouse his interest in the education of women, undermined his conviction of their intellectual inferiority. He had already been attracted, even dazzled, by the beauty, the friendships, and the vehement idealisms which he found at Castle Howard: Glasgow gave him the income-collected by himself in cash from the students-to propose to Lady Mary, 'consiliorum participi.' Ten years of work, 'impossibly hard,' ended in a breakdown. In I899 a doctor pronounced him 'permanently incapable of discharging his duties.' He resigned, and retired to Barford, near Churt, on a special Fellowship from New College.

Instead of dying as expected, Murray edited Euripides (I90I, I904, and I910). By modern professional standards he was not a methodical editor, and he would sometimes (as in his translations) wish a far-fetched meaning upon some MS reading which, not always for the right reasons, he chose to preserve. His assets were mental acuteness, sheer knowledge of Greek, and a strong resistance to what was poetically nonsensical. He never lost the strenuous enjoyment of reconstructing a text; the chief pleasure of his old age was his work with Paul Maas on the revision (I955) of his I 937 Aeschylus. When he edited Euripides he had already published some of his translations of Greek plays. More came out while he formed his long friendships with Bernard Shaw, the Granville Barkers, and actresses from Mrs. Patrick Campbell downwards. He was a born actor (especially in comedy, but his rendering of Choephoroe IO2 I ff. was magnificent), and his stage sense was brilliant, if not infallibly true to the original dramatist's. His translations have been more commonly judged by such pieces as that which he misquoted 'Could I take me to some tavern for my hiding' than by (e.g.) the splendid narrative of his Persae $384 \mathrm{ff}$. They delighted Shaw and many poets; letters of thanks came from unknown soldiers and trekkers in jungles; his Trojan Women was played by the Women's Peace Party of Chicago in 19I5 to keep America out of a war which he approved (his Foreign Policy of Sir Edward Grey appeared in that year). At Barford, the Boer War touched off his first public denunciation of nationalist mythology ('National Ideals; Conscious and Unconscious,' IFE 1900-Essays and Addresses, 1921, 160 ff.). This was the angry young man of Shaw's Major Barbara, in 'the lifelong struggle of a benevolent temperament and a high conscience against impulses of inhuman ridicule and fierce impatience.'

I This, with some other passages quoted below, is taken from papers still unpublished. 
In I908 Murray went to the Oxford Chair of Bywater, who had scribbled 'Insolent puppy' against the first words of Murray's preface to his Literature of Ancient Greece (I 897; republished I956). Murray had written to Sidgwick in 1894: 'I think a prophet is a good deal needed in Oxford to teach that there are really life and poetry ... in ancient literature. Bywater knows that this is so, but I doubt if he can make anyone else know it.' England was then at war with the Philistine. To crab Murray's technical erudition is to credit him with more than he desired or deserved. He deeply admired German scholarship, and confessed the difference: he was an amateur and an animateur. His Greek verse and prose compositions attest his supremacy in an English tradition of $\tau \epsilon^{\prime} \chi \eta \eta$, but only his secretaries know how incompatible with professional learning was his selfimposed obligation of response-instant, apt, and sensible - to the most preposterous calls upon his time. Meanwhile, his impact on the lecture-room can still be imagined from The Rise of the Greek Epic (1907), written in the prose of a speaking voice which later became famous on the air, carrying Homer straight to his hearers: ' $\kappa \in \hat{\imath} \tau o ~ \mu \epsilon^{\prime} \gamma a s \quad \mu \in \gamma a \lambda \omega \sigma \tau i$. . . the mighty limbs flung mightily, and the riding of war forgotten.' But Murray was not limited by 'public-schooligan classics.' He was led to translate Sallustius in his Four Stages of Greek Religion (1912; Five Stages in 1925). In all periods he showed his perception of what his successor at Oxford has called 'the Greeks and the Irrational.' His own 'rationalism' was based on an estimate of. human nature which was more Platonic than Pelagian: he recognized and distrusted 'the powers beneath reason which can deceive the brain and unnerve the hand.' His 'liberalism,' whether in party politics or in abolishing compulsory Greek, was simply his prescription of the treatment usually to be advised.

There is not space to speak of the absorbing work for peace which to him was a Hellenist's natural duty. As to his person, most readers of this Journal have seen or heard Gilbert Murray. They will give different answers to the question, What made the man greater than his various works? His mind, though always able to modulate and mature, had a coherence which was only reinforced by its blind spots (Shakespeare, music, Roman history). He knew 'that strange mixed passion, known to all artists, which consists, at its higher end, in the pure love of beautiful or noble creation, and, at its lower end, in conscious strain for the admiration of an audience' (The Greek Epic, ${ }^{2}$ 217). The unity of his life may be found, perhaps, in a continual awareness of dangerdanger to Greek studies or to civilized humanity - and in the unfailing response of a fighter.

M. I. H. 